Filozofska fakulteta, Univerza v Ljubljani dasa.stanic@ff.uni-lj.si

\title{
NUOVO MAGARI B2 IN NUOVO MAGARI C1/C2
}

De Giuli, A., Guastala C., Naddeo, C. M. (2013) Nuovo Magari B2. Firenze: Alma. (128 strani, 16.90 EUR)

De Giuli, A., Guastala C., Naddeo, C. M. (2013) Nuovo Magari C1/C2. Firenze: Alma. (288 strani, 24.90 EUR)

Pri glotodidakično ugledni založbi Alma (Firenze), ki že desetetja izdaja številna učna gradiva za poučevanje/učenje italijanščine kot tujega in drugega jezika, je v letošnjem letu izšla nova, prenovljena izdaja učbenika Magari z naslovom NUOVO Magari, ${ }^{166}$ in sicer tokrat kot dva ločena zvezka za dvoje različnih ravni znanja, z naslovoma NUOVO Magari B2 in NUOVO Magari C1/C2. Oba zvezka sta namenjena posameznikom, ki italijanščino že precej dobro obvladajo, in sicer je prvi namenjen za razvijanje oziroma doseganje ravni B2 (glede na Skupni evropski jezikovni okvir 2001, slov. izdaja 2011), drugi pa obsega besedila in naloge na ravneh $\mathrm{C} 1$ in $\mathrm{C} 2$.

Ena vidnejših sprememb letošnje izdaje je tudi sprememba glede določitve ravni, ki naj bi jih učbenik razvijal. Nova verzija, ki se sicer v marsičem razlikuje od starejših, vendar pa ne tematsko, vsebinsko in po težavnosti, je letos označena kot višja raven od obeh starejših izdaj, in sicer od B2 do C2 (starejše izdaje pa od B1 do C1). Nedvomno so $\mathrm{k}$ temu doprinesle tako učne izkušnje učiteljev in uporabnikov ter verjetno posledični (sicer vedno težavni) razmislek o tem, kakšno znanje je pravzaprav zajeto v opisnikih SEJO (2001, 2011), italijanščina kot tuji oziroma drugi jezik je namreč glotodidaktično bistveno manj raziskovana in raziskana kot npr. angleščina.

V Sloveniji je učbenik primeren za dvojezično območje slovenske Obale, lektorske vaje na fakulteti ${ }^{167}$ ter za nekoliko zahtevnejše tečaje italijanščine na omenjenih ravneh, nenazadnje pa tudi za katerega koli uporabnika, ki ima srednje visoko znanje italijanščine

166 Prva verzija učbenika je izšla leta 2008. Združevala je oba zvezka v enem in je bila namenjena ravnem B1 do C1 po Skupnem evropskem jezikovnem okvirju. Druga izdaja je izšla 2010 in je zajemala posebej učbenik in delovni zvezek, namenjena je (bila) prav tako kot prva ravnema B1 do C1 po Skupnem evropskem jezikovnem okvirju.

167 Na Filozofski fakulteti UL se starejši verziji učbenika že nekaj let uporabljata pri predmetih Italijanske lektorske vaje 1 in Italijanske lektorske vaje 2. 
in ki se želi ob besedilih (ljubiteljsko ali poklicno) poučiti o različnih vidikih italijanske družbe. Oba prenovljena dela, ki vključujeta v enem zvezku tako učbeniški del kot razdelek z učnimi nalogami (delovni zvezek), omogočata, da uporabniki razvijajo italijanščino na različnih področjih jezikovnega znanja: urijo bralno in slušno razumevanje, ustno in pisno sporazumevanje, slovnico, besedišče ter se obenem seznanjajo z italijansko kulturo in drugimi pojavi družbene stvarnosti. Oba zvezka imata na novo dodan sklop »attività video», zvezek za ravni $\mathrm{C} 1 / \mathrm{C} 2$ pa tudi dva posebna dodatka (poimenovana »extra«), kjer se dejavnosti in naloge navezujejo na odlomke književnih del nekaterih italijanskih avtorjev.

\section{VSEBINA IN STRUKTURA GRADIVA}

Učbenika NUOVO Magari B1 in NUOVO Magari C1/C2 imata podobno strukturo. Kazalu sledijo učne enote, priloge, razdelek z nalogami ob video posnetkih (ki so sestavni del tega učbeniškega kompleta), sklop z vajami (ki dopolnjujejo učne enote), testi za ponavljanje in utrjevanje, slovnična razlaga obravnavanih vsebin ter rešitve vaj razdelka »delovni zvezek«.

Kazalo je pregledno in podrobno: za vsako enoto navede najprej slovnične strukture in temo ozirom besedišče, temu sledita seznama besedil in posnetkov (za bralno in slušno razumevanje) ter navedki glede kulturno civilizacijskih elementov.

Učbenika sestavlja skupaj 21 učnih enot (v prvem zvezku enote od 1 do 9, v drugem pa od 10 do 21). Vseh enaindvajset enot se deli v pet tematskih sklopov, in sicer: geografija, umetnost, zgodovina, družba in jezik. Tematskim sklopom ni namenjen enoten obseg strani: geografiji sta posvečeni dve poglavji (Ue1 in Ue11) ${ }^{168}$, zgodovini tri (Ue4, Ue14, Ue20), družbi štiri (Ue3, Ue7, Ue12 in Ue16), jeziku štiri (Ue8, Ue15, Ue18 in Ue22) ter umetnosti sedem (Ue2, Ue6, Ue9, Ue10, Ue13, Ue17 in Ue19). Vsaka enota je tematsko zaokrožena in vsebinsko povezana $\mathrm{v}$ celoto, vključno s ponavljalnimi vajami ter $\mathrm{z}$ razdelkom »attività video« (za vsako Ue je na voljo po en krajši posnetek). Tematsko je učbenik pravzaprav bogata knjiga o italijanski sodobnosti, kulturi, zgodovini in geografiji, ki se navezuje tudi na aktualne družbene teme (Ue2 in Ue7), ki od učenca oziroma uporabnike knjige (tj. zainteresiranega posameznika), predpostavlja ne le (s)poznavanje jezika samega po sebi v okviru posamične teme, temveč tudi refleksijo in aktivno sodelovanje v diskusijah.

Največ prostora so avtorji namenili temi »umetnost« (»Arti«), ki pa je v učbeniku zastavljena $\mathrm{v}$ širokem pomenu in zajema raznolika besedila: od besedil o največjih italijanskih muzejih, o slikarstvu, filmu, literaturi in sodobni umetnosti, pa vse do razglabljanja o tem, kaj sploh umetnost je.

V primerjavi s starejšo izdajo je največja vsebinska sprememba na področju zgo- 
dovinskih tem. V novi verziji so avtorji zamenjali dve Ue s področja bližnje zgodovine oziroma družbene stvarnosti in ju nadomestili z dvema drugima, časovno precej starejšima zgodovinskima temama: tako so Ue4 Tangentopoli (v starejših verzijah) zamenjali z Ue4 Rinascimento, Ue9 z naslovom L'era di Berlusconi pa so nadomestili z Ue10 Stari Rim, s čimer so sicer zmanjšali družbeno-aktualni vidik o italijanski družbi, vsekakor pa dodali izjemno pomembni obdobji, ki sta zaznamovali ne le Apeninski polotok, pač pa tudi Sredozemlje in Evropo v celoti. Ostale tematike in vsebinske enote so pri novi izdaji ostale nespremenjene.

Učne enote so sestavljene po podobni organizacijski shemi: po uvodni nalogi sledi večinoma besedilo, ki predstavlja osrednji del učne enote ter, ne nujno v omenjenem vrstnem redu, naloge za bralno in slušno razumevanje, slovnične naloge ter naloge za učenje besedišča. Veliko prostora je namenjenega tudi nalogam oziroma spodbudam za govorno in pisno sporazumevanje, deloma tudi v obliki učnih iger (v dvojicah ali v skupinah). Z vsako učno enoto so tematsko povezani tudi ostali deli knjige: »video aktivnosti«, vaje ter predstavitev slovnice.

Na začetku vsake lekcije je »aktivni« uvod (»Introduzione«), sestavljen iz ene ali več nalog za učence, večinoma dobro premišljen, saj uporabnika uvede v temo učne enote. Večinoma gre za uvajanje tematike preko izvabljanja predhodnega poznavanja teme, marsikdaj pa zahteva od posameznika, da izpostavi tudi svoje mnenje o njej. Naloge uvodnega dela so raznovrstne: služijo za razvijanje slušnega razumevanja (posnetkov dialogov, odlomkov iz filmov, itd.), dodatna vprašanja na tematiko Ue, vprašalniki, dodatna krajša besedila, vaje za dopolnjevanje, aktivnosti za delo v dvojicah, pa tudi naloge ob obravnavanju pesmi in učne igre, redkeje pa slovnične strukture.

Prvemu delu Ue praviloma sledi besedilo (ali več krajših besedil iz različnih virov), ki zavzema osrednje mesto učne enote. Besedila so glede na raven in temo dobro izbrana, skoraj vsa so avtentična (le nekatera so delno prilagojena) ter zelo raznovrstna: časopisni članki, intervjuji, biografije, letaki, reklame, odlomki literarnih besedil, itd. Vsa besedila, ki so po navodilih avtorjev namenjena tihemu branju, so izhodišče za spremljajoče aktivnosti in naloge (opisane v nadaljevanju recenzije). Bralnemu razumevanju večinoma sledita tudi »analisi lessicale« in »analisi grammaticale«.

Utrjevanje in učenje slovnice je v knjigi zasnovano predvsem tako, da učenci zaznajo in opazujejo slovnične strukture, njihove funkcije in rabo v konkretnih (realnih) situacijah (znotraj besedila in dialogov). Učne enote niso sestavljene tako, da bi bila neka slovnična struktura v celoti obravnavana znotraj ene enote, ampak se iste slovnične strukture pojavljajo v različnih enotah, in s tem torej v različnih kontekstih (s čimer je zadoščeno vidiku cikličnosti glede obravnavanja slovničnih struktur). Tako se recimo »sestavljeni pogojnik « (ital. condizionale composto) obravnava v Ue2 v navezavi z (nesestavljenim) pogojnikom (ital. condizionale semplice), v Ue3 je obravnavana njegova raba za izražanje neuresničljive želje, kasneje se obravnava tudi v okviru sosledice časov 
(Ue17) in v pogojnih stavkih (Ue20).

Besedišče je obravnavano glede na kontekste (slušnih in bralnih besedil), večinoma se utrjuje $\mathrm{z}$ nalogami za njegovo rabo v nalogah, ki razvijajo (pisno in ustno) sporazumevanje. Veliko pozornosti avtorji namenijo tudi frazeološkim enotam, ki so pomemben pokazatelj poznavanja jezika, še posebej na višjih ravneh.

Obravnavanje slovničnih struktur in besedišča v kontekstu, usmerjenost na opazovanje funkcij in pomena znotraj konteksta ter zahteva po aktivnem sodelovanju posameznika, ki utrjuje ali se nadalje uči italijanščine kot tujega/drugega jezika, je zgolj ena od številnih pozitivnih lastnosti učbenika Nuovo Magari.

Prednost učbenika so tudi naloge za razvijanje komunikacijskih spretnosti v zelo različnih situacijah. Vemo, da je (pisna ali ustna) komunikacija učinkovita še zlasti takrat, ko zmore posameznik v določeni situaciji ustrezno uskladiti jezikovno in kulturno-civilizacijsko znanje. Aktivnosti za razvijanje sporočanja so različno (kognitivno) zahtevne: pri nekaterih je učenec precej voden, drugje je zelo prost. Predvsem drugi zvezek (za ravni C1/C2) vsebuje naloge z oznako »analisi della conversazione« in »analisi del discorso«, ki so namenjene opazovanju in pravilni uporabi intonacije, pavz, naglasov ter besedilnih označevalcev. Uporaba slednjih je pokazatelj dobrega znanja jezika, saj imajo pragmatično vlogo: organizirajo potek diskurza, ga povezujejo, kažejo na odnos do sogovornika, itd. in so kot taki pomemben del vsakdanjega pisnega in ustnega sporazumevanja.

Večina posnetkov, namenjenih slušnemu in »vizualnemu« razumevanju, je avtentičnih in zelo raznolikih (radijske oddaje, intervjuji, monologi, odlomki iz filmov, pa tudi pesmi in odlomki dramskih del), mnogi od njih soočijo učenca z različnimi italijanskimi narečji oziroma z narečno izreko. Video posnetki so praviloma izhodišče za niz/e nalog predvsem produktivnega tipa, ki se pridružujejo še ostalim nalogam, namenjenim pisnemu izražanju (sicer prisotnimi v vsaki enoti), ob katerih učenci na bolj ali manj voden način pišejo o temi učne enote

V knjigi skoraj ni nalog, ki bi bile namenjene izključno kulturno civilizacijskim vsebinam oziroma uravnoteženemu vzgajanju k vrednotam medkulturnosti, saj je ta vidik sam po sebi povezovalna rdeča nit učbenika in z njim so prepletene številne naloge in dejavnosti. Lahko rečemo, da posameznik oziroma učenec stalno spoznava (ali utrjuje predhodno poznavanje) kulturno civilizacijskih vsebin, pri čemer je vzgojni vidik impliciten oziroma se razkrije, ko te vidike učenec vključuje v svoje pisno ali ustno sporočanje glede obravnavane teme (pri čemer se pričakuje, da uporablja obravnavane slovnične strukture in besedišče, kar daje temu učbeniku posebno vrednost). Oba učbenika tako delujeta kot celota, skozi katero nas avtorji preko kulturno civilizacijskih aspektov vodijo $\mathrm{k}$ učenju jezika in njegovih različnih vidikov in funkcij.

V učbeniku C1/C2 sta tudi dve dodatni lekciji, imenovani »extra 1« in »extra 2«. Gre za učni enoti, ki jih starejši izdaji knjige nista vsebovali in katerih osnovna besedila pred- 
stavljajo odlomki znanih del italijanskih pisateljev, ki seznanijo študenta s še dodatnimi kulturno civilizacijskimi elementi in služijo za utrjevanje besedišča, slovničnih struktur ter komunikacije.

»Attività video« so tudi novost prenovljene verzije učbenika. Za vsako enoto so na koncu učnih enot prisotne naloge, ki se nanašajo na nek posnetek. Posnetki so različno dolgi (od tri do štirinajst minut) in so, kot besedila in slušni posnetki, avtentični in kot taki predstavljajo dodatno »dodano vrednost « učbenika. Njim namenjene naloge se nanašajo na razvijanje različnih zmožnosti (slušno razumevanje, pisno izražanje, ustno izražanje,....). So obenem značilen in zato odličen »posnetek « italijanske družbe in kulture ter hkrati prikaz uporabe italijanskega jezika, s poudarkom na frazeologiji ter pogovornem jeziku.

V vsaki enoti so umeščene tudi »pillole« in »box informativi«, ki v večini predstavljajo neko dodatno informacijo v zelo zgoščeni obliki. Gre za kratke zgodovinske preglede ali dodatne zanimivosti (biografije avtorjev, katerih odlomki so v knjigi, različne zanimivosti o Italiji, Italijanih in italijanskem jeziku, itd.). Nekateri »box informativi« so namenjeni tudi krajšim razlagam slovnice.

Delovni zvezek (v zadnjem delu knjige) ima enako število enot kot učbenik, nudi številne naloge za razvijanje receptivinih in produktivnih znanj (razumevanje in tvorjenje jezika), pri čemer gre večinoma za naloge s primarnim ciljem utrjevanja slovničnih struktur (povsem v ospredju je urjenje rab glagolskih oblik), nalog za utrjevanje besedišča je precej manj. Delovnemu zvezku sledita še dva testa, namenjena lahko tako samopreverjanju kot dodatni ponovitvi snovi.

Na koncu vsakega zvezka sta še razdelka s slovničnimi pregledom in rešitvami nalog (»Grammatica« in »Soluzioni«). V prvem so na kratko razložene slovnične strukture, obravnavane v Ue (vrstni red je glede na Ue v učbeniku) v drugem pa rešitve nalog delovnega zvezka in obeh testov.

Učbenika sta privlačna tudi na pogled in organizacijsko prijazna (tj. pregledna) do uporabnikov. Delujeta kot obsežnejša revija, vsebujeta veliko slikovnega materiala in sta zelo barvita, vendar z nevsiljivim slogom. Preglednost je pomembna odlika, npr. daljša besedila imajo oštevilčene vrstice ( $k a r$ je v veliko pomoč pri delu v razredu), naloge za dopolnjevanje tabel so smiselno umeščene v Ue, s čimer se zagotavlja učenčevo aktivno sodelovanje tudi pri urejanju snovi, $v$ duhu sistematičnosti in preglednosti.

\section{ZAKLJUČEK}

Omenjena učbenika predstavljata za učitelje italijanščine in za posameznike, ki se italijanščine učijo, izredno dober, pregleden in privlačen pripomoček za poučevanje/učenje italijanščine na ravneh B2 do C1, saj obsega vse tisto, kar naj bi dober učbenik tujega jezika obsegal. Visoko vrednost in uporabnost mu določajo nenehna smiselna prepletenost 
oziroma povezanost razvijanja štirih zmožnosti s kulturno civilizacijskimi vsebinami, učenje slovnice in besedišča v kontekstu, poudarek na komunikaciji ter tudi obe novi učni enoti ter dopolnitve v izdaji 2013. 